\title{
Covıd-19 Pandemisinin Toplum Ağız Diş Sağlığına Etkileri ve Etik Sorunlar
}

\section{The Impacts of the Covid-19 Pandemic on Dental Public Health and Ethical Issues}

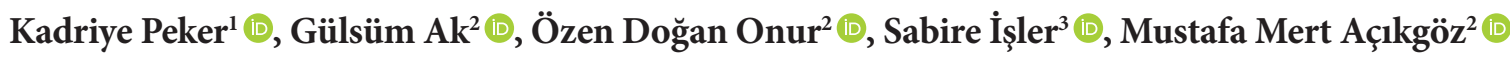

1 İstanbul Üniversitesi Diş Hekimliği Fakültesi, Temel Tıp Bilimleri Anabilim Dalı, İstanbul, Türkiye

2 İstanbul Üniversitesi Diş Hekimliği Fakültesi, Ağız, Diş ve Çene Cerrahisi Anabilim Dalı, İstanbul, Türkiye

3 İstanbul Üniversitesi Diş Hekimliği Fakültesi, Protetik Diş Tedavisi Anabilim Dalı, İstanbul, Türkiye

ORCID: K.P. 0000-0003-1436-6508;

G.A. 0000-0002-3339-1568;

Ö.D.O. 0000-0003-3659-4464;

S.İ. 0000-0002-1455-2127;

M.M.A .0000-0002-2346-1622

Sorumlu Yazar/Corresponding Author: Mustafa Mert Açıkgöz,

İstanbul Üniversitesi Diș Hekimliği Fakültesi, AğıZ, Diş ve Çene Cerrahisi Anabilim Dalı, İstanbul, Türkiye

E-posta: mertacikgoz@istanbul.edu.tr

Geliș tarihi/Submitted: 31.05 .2021 Kabul Tarihi/Accepted: 17.08.202

Online Yayın/Published Online: 20.10.2021

Atıf/Citation: Peker K, Ak G, Onur OD, Isler S, Acikgoz MM. The impacts of the Covid-19 pandemic on dental public health and ethical issues. Sağlık Bilimlerinde İleri Araştırmalar Dergisi 2021; 4(Suppl.1): S83-S95. https://doi.org/10.26650/JARHS2021-945653
ÖZ

COVID-19 pandemisi, ağız sağlığı eşitsizliklerinin artmasına, topluma yönelik ağız diş sağlığını geliștirme programlarının ve koruyucu ağız sağlığı hizmetlerinin kısıtlanmasına neden olmaktadır. Ortak risk yaklaşımına göre kronik sistemik hastalıklar ile aynı risk faktörlerini paylașan ağız hastalıklarının yönetilebilmesi için ağız sağlı̆̆ı hizmetlerinin birinci basamak sağlık hizmetlerine entegre edilmesi gerekmektedir. 'Tek Sağllk' konsepti benimsenerek halk sağlığı uygulamalarında multidisipliner çalışmalara ağırlık verilmelidir. Toplumun ağız sağlığı çıktılarını arttırmak için biyopsikososyal yaklaşım çerçevesinde sektörler arası işbirliği, çalışma esnekliği, kapasitesi, sosyal adalet, eşitlik ve insan hakları etik kuralları dikkate alınarak planlanan ağıZ sağlığını geliştirme programlarına ihtiyaç vardır. Toplumun "COVID-19 ve Ağız Sağlığı” konusunda okuryazarlığını arttırmak için enformasyon teknolojileri ve sosyal medya ağları kullanılmalıdır. Bu dönemde, sürveyans ve halk sağlığı çalışmaları vasıtasıyla toplumsal düzeyde ağıZ sağlığı ihtiyaç değerlendirilmesinin yapılması da önemlidir. Hareket kısıtlaması ve sağlığın sosyal belirteçleri nedeniyle ağız sağlığı hizmetlerine ulaşmada zorluk yaşayan dezavantajlı gruplar, çocuk ve yaşlılar için ağız sağlığının korunması ve geliştirilmesine yönelik programlara öncelik verilmelidir.

Anahtar Kelimeler: COVID-19, toplum diş hekimliği, sağlık hizmeti eşitsizlikleri, sağlığı geliştirme, koruyucu diş hekimliği, bilişim teknolojisi

\section{ABSTRACT}

The COVID-19 pandemic causes an increase in oral health inequalities, restriction of oral health promotion programs and preventive oral health services for the community. According to the common risk approach, oral health services should be integrated into primary health care services in order to manage oral diseases that share the same risk factors with chronic systemic diseases. Multidisciplinary studies should be focused on public health practices by adopting the "One Health" concept. In order to increase the popuation based oral health outcomes, there is a need for oral health promotion programs that take into account the cooperation between sectors, working flexibility, capacity,the ethical rules of social justice, equality and human rights within the framework of the biopsychosocial approach. Information technologies and social media networks should be used to increase the literacy of the population on "COVID-19 and Oral Health". In this period, it is also important to carry out oral health needs assessment at population level through surveillance and public health studies. Priority should be given to programs for the protection and improvement of oral health among disadvantaged groups, children and the elderly who have difficulty in accessing oral health services due to limitation of movement and social determinants of health.

Keywords: COVID-19, public health dentistry, health care inequalities, oral health inequality, health promotion, preventive dentistry, information technology 


\section{GİRIS}

Koronavirüs hastalığı 2019 (COVID-19), Dünya Sağlık Örgütü (DSÖ) tarafından 11 Mart 2020’de pandemi olarak ilan edilmiştir (1). Bu pandemi, dünya çapında en gelişmiş ülkelerde bile sağlık sistemlerini krize sokmakta, diş hekimliği mesleği ve halk sağlığı üzerinde ağır etkiler oluşturmaktadır. Mevcut sağlık sistemlerinin böyle bir krize yanıt verebilmesi için; diş hekimliği hizmetlerinde kapsamlı önleme ve kontrol stratejilerinin uygulanmasına, sağlık enformasyon sistemlerinin aktif kullanılmasına, diş hekimliği eğitim ve öğretim faaliyetlerinin ve metotlarının gözden geçirilmesine, ağız diş sağlığı alanındaki eşitsizliklerin giderilmesine, topluma yönelik ağız diş sağlığı çalışmalarının toplumun sağlık ihtiyaçları dikkate alınarak etik ilkeler doğrultusunda yeniden düzenlenmesine ihtiyaç vardır (2-8).

Ağız sağlığı genel sağlığın önemli parçasıdır. Bu dönemde, ortak risk yaklaşımı çerçevesinde ağız sağlığı hizmetlerinin genel sağlık hizmetleri içine entegre edilmesi ve diş hekimlerinin bütüncül bir anlayışla sağlık ekibinin içindeki aktif rolünün tanımlanması önem arz etmektedir $(7,9)$.

Virüsün genel sağlık etkilerinin yanında bireylerin ve toplumun ağız sağlığını, yaşam kalitesini ve iyilik halini etkileyen dolaylı etkileri vardır. Mevcut sağlık sisteminden ve sağlığın sosyal belirleyenlerinden (sosyal ve ekonomik faktörler) kaynaklanan bu dolaylı etkiler, bireysel ve toplumsal düzeyde ağız sağlığı hizmetine erişimi kısıtlanmaktadır. Acil tedaviler dışında rutin ağız sağlığı hizmetlerinin ertelenmesi ve enfeksiyon kontrol prosedürleri kapsamında daha az hastaya ağız sağlığı hizmeti verilmesi, ağız sağlığında eşitsizliklerin ve ağız hastalıklarının yükünün artmasına neden olacaktır (7-10).

Pandemi döneminde, bireylerin yaşadığ 1 virüse yakalanma ve toplumla ilişkide olma korkusu gibi psiko-sosyal problemler, gelirin ve alım gücünün azalmasına bağlı olarak beslenme ve ağız hijyeni temininde yaşanan zorluklar, davranışsal ve kültürel yatkınlığa bağlı olarak sağlığa zarar veren davranışlarda artma (artan ara atıştırma sayısı, alkol tüketimi ve sigara kullanımı, düşük fiziksel aktivite, diş hekimi kontrollerinin azalması), sosyo-ekonomik eşitsiz- likler ve çalışma yaşamıyla alakalı olumsuzluklar, ekonomik gerileme, durgunluk ve artan borçlar, hükümetlerin ağız sağlığı hizmetlerinin finansmanında yaşadıkları zorluklar hem ağız sağlı̆̆ını hem de genel sağllğ veren davranışların ve olumsuz yaşam koşullarının, toplumda özellikle COVID-19 açısından risk grubunda olanlarda ağırlık kazanması var olan ağız sağlığ eşitsizliklerinin derinleşmesine neden olmaktadır $(7,9,10)$.

$\mathrm{Bu}$ nedenle, toplum düzeyinde ağız sağlı̆̆ını geliştirmeye yönelik programlar ve faaliyetler COVID-19 genel halk sağlığı uyarılarının (sosyal mesafe, maske kullanma, el hijyeni) paylaşıldığ programlara entegre edilmelidir. Makro düzeyde (politika geliştirme ve gündem belirleme) gerçekleştirilecek ağız sağlığını geliştirme çalışmalarında, "COVID-19 ve ağız sağlığı" konusunda toplumu bilinçlendirmek ve gündem belirlemek için kitle iletişim araçlarının kullanımı gerekmektedir. Bu uygulamaların yanında, sağlıklı davranışların gelişimini destekleyici çevrelerin oluşturulmasına pandemi döneminde daha fazla önem verilmelidir $(9,10)$.

Pandemi döneminde, ağız sağlığı halk sağlığına yönelik acil konular kapsamında ihmal edilmiştir. Halk sağlığına yönelik uygulamalar kapsamında; diş hekimliği hizmet sunumunda uygun güvenlik önlemlerinin sağlanması, doğru triyaj ve hastaların önceliklendirilmesi, duyarlı toplulukların saptanmas1, sağlığı geliştirme çalışmaları, topluma yönelik ağız diş sağlı̆̆ hizmetlerinde bilişim sistemlerinin kullanılması, COVID-19 epidemiyolojik raporlarının ve güncel bilgilerinin takibi, sürveyans analizi ve raporlama önemli konular olarak karşımıza çıkmaktadır (4,7-11).

\section{COVID-19 ve Ağız Sağlığı Hizmetleri}

3 Ağustos 2020 tarihinde DSÖ tarafından yayınlanan" COVID-19 Pandemisinde Temel Ağız Sağlığı Hizmetlerinin Sağlanmasına İlişkin Hususlar” başlıklı rehberde, ağız sağlığı problemlerinin önlenmesi ve bireysel ağız bakımının sağlanmasının önemine dikkat çekilmekte ve hastaların uzaktan danışma veya sosyal medya aracılığ 1 ile ağız hijyeninin sağlanması konusunda bilgilendirilmesi önerilmektedir. DSÖ, 
ulusal ve yerel otoriteler tarafından vaka sayılarının azaldığ 1 ve kontrol altına alındığı bildirilinceye kadar diş hekimi kontrolü, diş temizliği ve koruyucu diş hekimliğini içeren "rutin acil olmayan ağız sağlığı tedavilerinin" azaltılmasını önermektedir (12).

Mevcut sağlık sistemi ve ağız sağlı̆̆ı hizmetlerinin bu sistem içindeki yeri, halkın ağız sağlığı düzeyini etkilemektedir. Ortak risk yaklaşımı çerçevesinde, ağız hastalıkları kronik sistemik hastalıklar ile aynı risk faktörlerine sahiptir. Sağlı̆̆ın, yaşam kalitesinin ve üretkenliğin sürdürülmesi için ağız sağlığı hizmetlerinin birinci basamak sağlık hizmetlerine entegrasyonu gerekmektedir. COVID-19 pandemisiyle birlikte, "temel ağız sağlığı hizmeti kavramı" yeniden tartışılmaya başlanmıştır. Benzian ve ark. Tarafından, acil ve temel ağız sağlığı hizmetlerinin yanı sıra ileri uzmanlık gerektiren diş hekimliği hizmetlerini de bütünleştiren katmanlı bir “Temel Ağız Sağlığı Hizmet Modeli” önerilmiştir (13). Bu dönemde, ağız sağlığı hizmetlerinin temel sağlık hizmetlerinin ayrılmaz bir bileşeni olduğu ve ağı sağlı̆̆ hizmeti sunan personelin de temel sağlık hizmetleri iş gücünün bir parçası olduğu dikkate alınmalıdır. Tüm ağız diş sağlığı hizmetleri gerekli ağız sağlı̆ğ hizmetleri kapsamında değildir ve pandemi döneminde mevcut kriterlere ve kanıtlara göre "minimum temel ağız sağlığı hizmet paketi” belirlenmelidir. Bu paket kapsamında, hangi müdahalelerin verileceği tüm paydaşların (akademik, klinik topluluklar, profesyonel kuruluşlar ve sivil toplum) yer aldığı bir konsensüs tarafından belirlenmelidir. Bu paket oluşturulurken lokal düzeyde toplumun ihtiyaçları, hastalık yükü, kültür, sağlık öncelikleri, politik destek düzeyi, mevcut sağlık ve finansman kaynakları dikkate alınmalıdır (13).

Temel ağız sağlı̆̆ 1 hizmetleri, üzerinde uzlaşılan güvenli, kaliteli ve uygun maliyetli müdahaleleri içermektedir. Bu hizmetler; prevalansı yüksek ağız hastalığı ve problemlerin önlenmesi ve ağız sağllğını geliştirme çalışmaları ile bu hastalık ve problemlerin tedavi ve rehabilite edilmesi basamaklarını içermektedir. Bu bağlamda, 'minimum temel ağız sağlığ hizmet paketi’ ise sağlık güvencesi kapsamında herkes tarafından ulaşılabilir güvenli, düşük maliyetli ve sık görülen ağı hastalıkları ve problemlerinin çözü- müne odaklanan ağız sağlığı hizmetlerini kapsamaktadir (13).

Toplumun ağız sağlığı sorunlarının etkin olarak çözülebilmesi için, öncelikli olarak tedavi hizmetlerinde yerel COVID-19 epidemiyolojisine göre triyaj ve önceliklendirme işlemlerinin yapılması önemlidir. Hasta ve topluma yönelik birinci basamak ağız sağlığı hizmetleri kapsamında ise tele-diş hekimliği ve çevrimiçi ziyaretler gibi uzaktan diş hekimliği uygulamaları vasıtasıyla ağız sağ lı̆̆ını geliştirme programlarının sunulması gerekmektedir (4,7-11,13).

\section{Ağız Sağlığında Eşitsizlikler}

COVID-19 küresel salgınının sağlıkta, ekonomik alanda ve sosyal yaşamda yarattığı olumsuz etkiler toplumların iyilik hali ve yaşam kalitesini düşürmekte ve sağlık hizmetlerinin sunumu ve hizmetten yararlanma aşamasında sorunlara neden olmaktadır.

Pandemi döneminde artış gösteren ağız sağlı̆̆ eşitsizliklerinin temelinde sağlik sistemine ve sağlı̆̆ın sosyal belirleyenlerine bağlı faktörler yer almaktadır. Yoksulluk, eğitimsizlik, evsizlik, düşük sosyo-ekonomik grupta yer alma, olumsuz fiziksel çevre, göçmenlik, rrk ve etnik köken gibi sosyal belirleyenler, hem hastalığa yakalanma riskini, prognozunu ve komplikasyonlarını etkilemekte hem de ağız sağlı̆̆ hizmetlerine ulaşımda zorluk yaşayan kırılgan grupların oluşmasına neden olmaktadırlar $(7,14)$. Ağız sağlı̆̆ hizmetlerinin yerel popülasyonun ihtiyaçlarına cevap verecek şekilde düzenlenmesi gereklidir. Bu aşamada, kronik sistemik hastalık riski fazla, bakıma muhtaç, düşük gelir ve eğitim düzeyine sahip kırılgan grupların ağız sağlığı hizmetlerine ulaşmasını kolaylaştıracak bir hizmet yaklaşımı sergilenmelidir (8). Ağız sağlı̆̆ı hizmetlerine erişimi etkileyen faktörleri; psiko-sosyal problemler, sağlığa zarar veren davranışların artması, gelirin ve alım gücünün azalmasına bağlı olarak ağız bakımının ve diş hekimi kontrollerinin azalması, ekonomik gerileme, durgunluk ve artan borçlar, hükümetlerin ağız sağlığı hizmetlerini finansmanında yaşadığı zorluklar olarak özetleyebiliriz $(9,10)$. Bu pandemiden elde edilen deneyimler, ileride yaşanacak pandemi ve diğer halk sağlı̆̆ı acil durumlarının başarı ile yönetilebilmesi için tüm paydaşlara yol gösterici olacaktır. Sağllğın 
sosyal belirleyenleri, halk sağlına yönelik stratejilerin, politikaların ve multidisipliner bilimsel araştırmaların bir parçası olarak ele alınmalıdır (7-10,14).

COVID-19 pandemisi, hem ağız diş sağlığı hizmeti alan bireyler hem de hizmeti sunanlar için var olan ekonomik sorunları arttırmıştır. Bireyler ekonomik sıkıntılar nedeniyle cepten -ödeme yaparak özel ağız diş sağlı̆̆ 1 kurumlarından hizmet almada zorluk yaşamada ve sosyal güvenceleri kapsamında olan kamu kurumlarını tercih etmek zorunda kalmaktadır. Mevcut sağlık sektöründe iş gücü, işleyiş protokolleri, malzemelerin tedarik zinciri ve nakit akışında yaşanan sorunlar toplumun hizmetten yararlanma olanağını kısıtlayacaktır. Dünya çapında hükümetlerin ana hedefleri arasında pandemi yayılımının azaltılması ve COVID-19'un ekonomik yükünün hafifletilmesi yer almaktadır. Ekonomik anlamda, diş hekimliği hizmetlerinde kısıtlama ve azaltma önlemlerinin uzun süreli uygulanması halinde ağız sağlı̆̆ı hizmeti veren özel kurumlardaki mali sıkıntı artacak ve özellikle operasyonel maliyeti yüksek olanlar daha fazla etkilenecektir. Ağız sağlığı karar vericileri ve politika yapıcıları, ağız sağlı̆̆ hizmetlerine erişimi artırmak için mevcut ihtiyaçlar ve kaynakları dikkate alarak yeni planlamalar yapmalıdırlar. Bu süreçte, mevcut politikaların ağız hastalıklarının korunması ve ağız sağlığının geliştirilmesini ön plana çıkaracak şekilde iyileştirilmesi ve hizmet sunumunda işgücü ve geri ödemenin önündeki engelleri kaldıracak tarzda yeni finansal düzenlemelerin yapılması gerekmektedir $(2,8,15,16)$.

Ülkemizde olduğu gibi birçok ülkede çocuklar ve yaşlılar, kısıtlamalar nedeni ile ağız sağlığı hizmetine ulaşmada zorluk yaşayan grupların başında gelmektedir. Sosyal haklardan mahrum ailelerin çocukları arasında ağız diş sağlığına bağlı eşitsizlikler artmaktadır. İş yerlerinin kapanması ve işsizliğe bağlı maddi sıkıntılar nedeni ile aileler çocuklarının ağız hijyeni için gerekli olan en basit malzemeleri bile temin edememekte ve cepten harcama yaparak ağız diş sağlığı hizmeti alamamaktadır. İşsizlik nedeniyle sosyal güvencesi olmayan ailelerin çocukları, kamu ağız diş sağlığı hizmetlerinden yararlanamamaktadır. Bu dönemde, birinci basamak ağız diş sağlığı hizmet- lerinin aktif olarak sunulduğu ülkelerde bile, kısıtlamalar nedeniyle minimal invaziv tedaviler ve koruyucu uygulamalarda gecikmeler yaşanmaktadır. $\mathrm{Bu}$ durum, diş çürüklerinin ve tedavi gereksiniminin artmasına neden olacaktır $(17,18)$.

Bunun önüne geçmek için, mevcut ağız diş sağlığ 1 politika ve stratejilerinin pandemi dönemi de dikkate alınarak gözden geçirilmesi ve toplumda çocuklara yönelik ağız sağlığını geliştirme programlarının uygulanmasına öncelik verilmesi gerekmektedir $(17,18)$. Bu amaçla, tüm sağlık çalışanları (pediatristler, pratisyen hekimler, diş hekimleri ve hemşireler), ebeveynler, okullar ve diğer kurumlar işbirliği içinde çalışmalıdır.

Ülkemizde ağı diş sağlığı hizmetleri, birinci basamak sağlık hizmetlerinin içine tam anlamıyla entegre edilememiştir. Çocuklara yönelik koruyucu uygulamalar, ücretsiz olarak kamu ağız diş sağlı̆̆ kurumlarında uygulanmasına rağmen yararlanım yüzdesi oldukça düşüktür (19). Okul ağız diş sağlığı hizmetleri etkin olarak yürütülememektedir. Sağlık Bakanlığı tarafından anaokulu ve ilkokul öğrencilerinde yürütülen koruyucu ağız ve diş sağlı̆̆ progra$\mathrm{m}$ kapsamındaki florlu vernik uygulaması ve sağlık eğitimi çalışmaları pandemi nedeniyle kesintiye uğramıştır (20). Topluma yönelik olarak diş hekimliği fakülteleri ve diş hekimleri odaları vb. kurumlar tarafından çocuklarda, hamilelerde ve yaşlılarda yürütülen ağız sağlığı eğitimi ve ağız sağlığını geliştirici programlar da pandemi döneminde uygulanamamaktadır.

Ülkemizde, Üstün ve ark. tarafından yapılan bir çalışmada, acil olmayan rutin diş hekimliği hizmetleri kapsamında özellikle koruyucu diş hekimliği uygulamalarında (fissür örtücü, flor tedavisi) ciddi oranda düşme olduğu, diş kliniğine başvuru nedeni olarak acil diş hekimliği şikayetlerinin ön plana çıktığı görülmektedir (21). Pulpitise bağlı diş ağrısı, apse ve şişlik en sık bildirilen acil diş hekimliği şikâyetler arasında yer almaktadır.

Pandemi döneminde artan tedavi ihtiyacı dikkate alınarak çocuk popülasyon için koruyucu ağız ve diş sağllğ 1 hizmetlerinin birincil, ikincil ve üçüncül koruma basamaklarını içerecek şekilde düzenlenme- 
si gerekmektedir. Birincil koruma kapsamında, her çocuğa şeker tüketimi ve ara atıştırma sıklığının azaltılması, diş firçalama ve florlu diş macunu kullanmanın önemini vurgulayan ağız sağlığı eğitimlerinin verilmesi; ikincil ve üçüncül koruma kapsamında ise diş çürüklerinin erken teşhisi, çürük risk grubuna göre fissür örtücü ve topikal flor uygulamalarının yapılması ve minimal invazif müdahale tekniklerinin uygulanması önerilmektedir (22).

Diğer bir kırılgan grup olan yaşllar, viral enfeksiyon açısından yüksek risk altındadır. Bu süreçte, kısıtlamalar nedeniyle yaşlıların hem ağız sağlığı hem de genel sağlık kontrolleri ve tedavileri aksamıştır. Ortak risk yaklaşımı çerçevesinde karşılıklı etkileşim halinde olan ağız hastalıkları ve kronik hastalıkların tedavisi ve kontrolünde yaşanılan problemler, olası komplikasyonları ve enfeksiyonlarını tetikleyerek yaşlıları pandemi döneminde daha da duyarlı hale getirmektedir. Özellikle yaşlılarda uygulanacak birinci basamak koruyucu diş hekimliği uygulamalarının başında; diş çürüğünü kontrol altına almak için yüksek konsantrasyonda flor içeren diş macunlarının kullanılması, günlük ağız bakımının sağlanması, sağllğa zarar veren sigara içme davranışının önlenmesi gelmektedir. Bağımlı yaşlı insanları da kapsayacak şekilde ağız sağlığını geliştirme programlarının oluşturulmasına ve ağı sağlığı hizmetlerinin bu grubun ihtiyaçlarına cevap verecek şekilde multidisipliner bir anlayışla planlanmasına acil bir ihtiyaç vardir $(18,23)$.

\section{COVID-19 Pandemisinde Topluma Yönelik Koruyucu Diş Hekimliği Uygulamalarının Öne-} mi

Tedavi uygulamalarında koruyucu ve minimal invazif uygulamalarının ağırlık kazandığı pandemi döneminde, bireylerin ve toplumun ağız sağlığının korunması ve geliştirilmesine yönelik çalışmalara da ağırlık vermek gerekmektedir $(11,12,24)$. Bu çalışmalar, toplumdaki ağız sağlı̆̆ eşitsizliklerinin azaltılmasına da katkı sağlayacaktır $(7,9,25)$.

DSÖ’nün 3 Ağustos 2020 tarihli “COVID-19 Bağlamında Temel Ağız Sağlığı Hizmetlerinin Sağlanmasına İlişkin Hususlar” başlıklı ara rehberinde, COVID-19 pandemisinde 'kişisel ağız hijyeninin sağlanmasının' bir öncelik olmaya devam ettiği görülmektedir. Pandemi döneminde, hem ağız hastalıklarının yönetilmesinde hem de COVID-19 tanısı konulmuş hastalarda komplikasyon riskinin azaltılmasında ağız hijyeni ve koruyucu diş hekimliği uygulamaları önem arz etmektedir. Hem hastalara hem de topluma optimum ağız hijyeninin sağlanması konusunda uzaktan konsültasyon veya sosyal medya kanalları aracılığıyla gerekli bilgilerin verilmesi gerekmektedir (12). Bu bağlamda, ağız sağlığı hizmet sağlayıcıları, hastaları COVID-19 salgını sırasında ağız sağlıklarını nasıl koruyacakları ve evde yapacakları ağız hijyeni uygulamaları konusunda eğitmeli ve bu uygulamaların önemi konusunda bilgilendirmelidirler $(12,26)$. Ağız hijyeninin iyi olması, diş hekimliği tedavi hizmet ihtiyacını azaltacağı gibi günlük yaşamda virüsün bulaşma olasıllı̆̆ da azaltmaya yardımcı olacaktır. Diyabet, yüksek tansiyon veya kardiyovasküler hastalık nedeniyle biyofilm değişikliklerine yatkın hastalarda, iyi ağız hijyeni ağızdaki bakteri yükünü ve bakteriyel süper infeksiyon riskini de azaltacaktır $(27,28)$.

Standart ağız hijyeninin sağlanmasında, diş fırçalama, ara yüz temizliği, dil temizliği, antibakteriyel gargara kullanımı önerilmektedir. Antiviral gargaralar, tedavi öncesi hastaların tükürügündeki viral yükü ve transmisyonu azaltmak ve COVID-19'lu hastalarda ise ağız florasıyla alakalı sistemik problemleri iyileştirmek için kullanılmaktadır $(29,30)$. Tedavi öncesi gargara kullanımı ile hastalığın bulaşmasının önlenmesi, diş hekimliği ofislerinin açık kalmasina ve tedavi hizmetlerinin sürdürülmesine yarar sağlayacaktır. Ağız hijyeninin temininde antiviral gargaraların etkinliğini test eden COVID-19 insan çalışmaları gözden geçirildiğinde, randomize kontrollü klinik çalışmaların devam ettiği görülmektedir.

Ağız gargaralarının ve spreylerin COVID-19 bulaşını önlediği yönündeki bilgiler toplumla paylaşılırken dikkat edilmesi gerekmektedir Toplum, günlük ağız hijyenin sağlanması, hekim önerisi doğrultusunda kimyasal plak kontrolü için ağız gargaralarının kullanımı (setilpiridinyum klorür, povidon-iyot ve etanol/etil laurol arginat) ve ağız gargaralarının tek 
başına diş fırçalamanın yerine kullanılmayacağı konusunda bilgilendirilmelidir. Pandemide, ağız gargaralarının sosyal etkileşimlerden önce ve sonra kullanımının bulaşma riskini azaltmadaki rolünün belirleneceği klinik araştırmalara ihtiyaç vardır (31).

COVID-19 Pandemisinde Topluma Yönelik Ağız Sağlığını Geliştirme Programlarının Önemi

Pandemi döneminde topluma yönelik ağız sağl1ğ1 geliştirme programları, ağız hijyeni uygulamalarının yanında tütün ve alkol kullanımıyla ilişkili risk faktörlerinin azaltılması, daha sağlıklı beslenme tarzının teşvik edilmesi ve diş çürüklerinin önlenmesine yönelik topikal flor uygulamalarını da içermelidir. Bu kapsamda, ağız sağlığı eğitimi vasıtasıyla olumlu ağız sağlığı davranışlarının geliştirilmesi, beslenme danışmanlığ firçalama ve diş ipi kullanma), toplumsal bazda kanıta dayalı flor uygulamaları, tütün ve alkol tüketiminin azaltılması ve diş travmalarından kaçınma gibi ağız sağlığına yönelik riskleri kontrol etmeye yönelik bilinçlendirme programları ve sağlı̆̆ geliştiren ortamlar oluşturma çalışmaları yer almalıdır. Bütün bu uygulamaları başarıyla yürütebilmek için ağız sağlığını geliştirmeyi önceleyen sağlık politikalarının da mevcut sağlık sistemi içinde yer alması önem taşımaktadır. Ağız sağlığını geliştirme faaliyetleri, COVID-19 halk sağlığı programlarına entegre edilmeli ve multidisipliner bir yaklaşımla yönetilmelidir.

Diş hekimleri, evrensel önlemleri ve güncel epidemiyolojik bilgileri dikkate alarak halkı hem önleyici hem de rutin ve acil ağız sağlığı hizmeti konusunda bilgilendirmekle sorumludur (11).

COVID-19 pandemisinde, farklı ülkelerde diş hekimliği birlikleri tarafından toplumun bilgilendirilmesi amacıyla broşürler ve materyaller hazırlanmıştır. Hem internet aracılığıyla bilişim teknolojilerini kullanarak hem de yazılı olarak ulaşabilen bu materyallerde, ağız ve burunun koronavirüs için ana giriş kapısı olduğu, ağız bakımının önemi ve ağız sağlığı- genel sağlık ilişkisi vurgulanmıştır.

İrlanda Diş Hekimliği Birliği'nin 'Diş Firçalama ve COVID-19' (32), Kanada Ağız Hijyenistleri Birliği’nin 'COVID-19 Döneminde Ağız Bakımı' (33), Dünya Dişhekimleri Birliği’nin (FDI) 'COVID-19
Salgını Sırasında Ağız Sağlığınızı Koruyun'(34) adlı bilgilendirme kaynaklarında; diş fırçalama, ara yüz temizliği, beslenme, sigara ve alkolden uzak durma, diş hekiminden danışmanlık alma ve genel korunma önlemleri olmak üzere alt başlıkların yer aldığı görülmektedir. Tablo1'de bu broşürlerde yer alan ağız sağlığı mesajları özetlenmiştir.

Bu dönemde, FDI tarafından Birleşmiş Milletler Eğitim, Bilim ve Kültür Örgütünün savunmasız ve dezavantajlı topluluklar için okul kapanışlarının etkilerini hafifletmek, öğrenme kayıplarını ele almak ve eğitim sistemlerini uyarlama çabaları dikkate alınmıştır. FDI, bu dönemde ebeveynleri ve öğretmenleri çocukların ağız sağlığı hijyeninin sağlanması konusunda okulda ve evde "Mouth Heroes" adlı dijital ağız sağlığı eğitimi kaynaklarıyla desteklemektedir (35).

Ülkemizde, topluma yönelik 'COVID-19 ve Ağız Sağlığı' konusunda sağlık okuryazarlığını arttırmaya yönelik çalışmaların etkin olarak yürütülemediği, salgın döneminde ağız sağlı̆̆ının korunması ve yapilması gereken bireysel uygulamalar konusunda sosyal medya ve bazı diş hekimliği merkezlerinin ve hekimlerin kendi kişisel web sayfalarından yaptıkları çalışmaların olduğu görülmektedir. Ülkemizde genel okuryazarlık düzeyinin ortalama 8 yıl olduğu dikkate alındığında, dezavantajlı grupların sosyal medya ve bilgisayar kullanarak doğru bilgiye ulaşmada zorluk yaşayacağı gerçeği ortaya çıkmaktadır. Topluma yönelik bilgilendirmelerde ağız sağlığının genel sağlığın ayrılmaz bir parçası olduğu özellikle vurgulanmalıdır. Toplumun ağız diş sağlığı hizmetlerini nereden ve nasıl alacağ 1 , farklı yaş gruplarının ve bakım ihtiyacı olan bireylerin ağız sağlığını korumak için yapması gerekenler konusunda bilgilendirileceği hem yazılı ve hem de medya aracılığıyla kanıta dayalı ağız sağlığı okuryazarlığını arttırma çalışmaları planlanmalıdır.

Bu bağlamda, Sağlık Bakanlığ "COVID-19 Bilgilendirme Platformu”na ağız sağlığı ve COVID-19 ilişkisi, pandemi döneminde evde ağız bakımı ve hijyeni nasıl sağlanmalı, ağız diş sağlığı hizmetleri nasil ve nereden alınacak konularında kanıta dayalı bilgilerin aktarıldığ 1 bir yapılanma fayda sağlayacaktir. 


\begin{tabular}{|c|c|c|c|}
\hline Diş Furçalama & $\begin{array}{l}\text { Arayüz temiz- } \\
\text { liği }\end{array}$ & $\begin{array}{l}\text { Beslenme ve Riskli Sağlık } \\
\text { Davranışları }\end{array}$ & Diş Hekimi Kontrolüi \\
\hline $\begin{array}{l}\text {-Florlu diş macunu ile günde iki kez ve } \\
\text { minimum } 2 \text { dakika diş fırçalama } \\
\text {-Fırçalama sonrası diş fırçasını } 2 \text { dakika } \\
\text { sıcak su altında yıkama } \\
\text {-Diş fırçalarken sosyal mesafeye uyma, } \\
\text { lavaboda tek kişi olacak şekilde fırçala- } \\
\text { ma } \\
\text {-Diş fırçalarını birbirine temas etme- } \\
\text { yecek şekilde bir bardak veya özel fırça } \\
\text { kaplarında saklamak. Mümkünse fırça } \\
\text { kapakları kullanmak } \\
\text {-Çocukların fırçalarının üzerine silin- } \\
\text { mez bir kalemle ismini yazma, okumayı } \\
\text { henüz öğrenmemiş çocuklar için farklı } \\
\text { nitelikte fırçalar kullanma, } \\
\text {-Fırçayı lavaboya ve diğer yüzeylere } \\
\text { koymama. Enfekte olan kapakları sıcak } \\
\text { su altında, bulaşık makinesinde sıvı } \\
\text { deterjanlar ile yıkama } \\
\text {-Mümkünse tuvalet dışında bir yerde diş } \\
\text { fırçalama } \\
\text {-Diş macununun ortak kullanıldığı du- } \\
\text { rumlarda, aile içi bulaşı önlemek için diş } \\
\text { macununu direkt fırçanın üzerine koy- } \\
\text { mama. Tek kullanımlı bir çubuk veya } \\
\text { bir kaba kullanacağınız kadar macun } \\
\text { sıktıktan sonra fırça ile bunu kullanma } \\
\text {-Ortak havlu kullanmama } \\
\text {-Diş çürüklerini önlemek için hekim } \\
\text { önerisi doğrultusunda fırçalama sonrası } \\
\text { florlu gargara kullanma } \\
\text {-Her } 3 \text { ayda bir veya hastalanıldığında } \\
\text { dişı̧asının değiştirilmesi } \\
\text {-Hasta kişilerin kişisel eşyalarını ve diş } \\
\text { fırçalarını kullanmama } \\
\text {-Funın mümkün olmadığı du- }\end{array}$ & $\begin{array}{l}\text {-Günde bir kez } \\
\text { diş ipi kullanma } \\
\text {-Kullanılan diş } \\
\text { ipi ve arayüz } \\
\text { fırçalarını tekrar } \\
\text { kullanmama } \\
\\
\text {-Her gün hekim } \\
\text { tarafından öne- } \\
\text { rilen antibakte- } \\
\text { riyel gargaranın } \\
\text { kullanılması }\end{array}$ & $\begin{array}{c}\text { - Yetişkinler altı çay ka- } \\
\text { şığından, çocuklar } 3 \text { çay } \\
\text { kaşı̆̆gndan fazla şeker tüket- } \\
\text { memelidir. Düşük şeker ve } \\
\text { yüksek düzeyde taze sebze ve } \\
\text { meyve içeren dengeli bir diyet } \\
\text { uygulama } \\
\text {-Öğgün aralarında şekerli atış- } \\
\text { tırmalıklar tüketilmemelidir } \\
\text {-Öğün aralarında elma, kuru- } \\
\text { yemiş, sade yoğurt gibi sağ- } \\
\text { lıklı yiyecekler tüketilmelidir } \\
\text {-Günde } 3 \text { ana, } 2 \text { ara öğün ile } \\
\text { beslenmek } \\
\text {-Tatlılar sadece yemekle bir- } \\
\text { likte tüketilmeli } \\
\text {-Ana içecek olarak suyu ter- } \\
\text { cih etmek } \\
\text {-Yemeklerden sonra diş fır- } \\
\text { çalama imkânı yoksa şekersiz } \\
\text { ksilitollü çiklet çiğneme } \\
\text {-Düzenli olarak tüketilen } \\
\text { şekerli içecekler (yaklaşık } \\
\text { günde bir kutu) sadece ağız } \\
\text { sağlığını değil Tip } 2 \text { diyabet } \\
\text { ve obezite riskini de arttırır. } \\
\text {-Alkol ve sigara kullanmama }\end{array}$ & $\begin{array}{c}\text {-Bölgesel COVID-19 duru- } \\
\text { muna göre, diş hekimi kont- } \\
\text { rol randevusunun ertelenip } \\
\text { ertelenmeyeceğini diş heki- } \\
\text { minden öğrenmek } \\
\text {-Ağrı, kanama, diş kırılması } \\
\text { gibi acil durumlarda zaman } \\
\text { kaybetmeden diş hekimliği } \\
\text { hizmeti veren kurumları } \\
\text { arama ve randevu alma } \\
\text {-Herhangi bir diş problemi } \\
\text { için profesyonel yardım alma, } \\
\text { evde kendi başına tedavi } \\
\text { etmeye çalışmama } \\
\text {-Çocuklar ve bakım ihtiyacı } \\
\text { olanlar dışındaki bireylerin } \\
\text { tek kişi olarak randevularına } \\
\text { gitmeleri } \\
\text {-Bekleme odasında diğer } \\
\text { hastalarla olan teması mi- } \\
\text { nimuma indirmek için tam } \\
\text { zamanında randevuya gitme } \\
\text {-Muayene odasında sosyal } \\
\text { mesafeye uyma ve maske } \\
\text { takma } \\
\text { minden bilgi alınmalıdır. } \\
\text { teması olanların "ne yapması } \\
\text { gerektiği” hakkında diş heki- } \\
\text { unma } \\
\text {-Kurumda ve muayenehane- } \\
\text { de belirtilen genel kurallara } \\
\text { - } \\
\text {-Ulusal ve bölgesel uyarılar } \\
\text { ve kararlar dikkate alınarak } \\
\text { diş hekimine gitme } \\
\text { coviD-19 pozitif, semp- }\end{array}$ \\
\hline
\end{tabular}

COVID-19 çapraz enfeksiyon riskini ve yayılımı azaltmak için ebeveynlere verilecek bilgilendirmelerde; sosyal mesafe, el hijyeni, düzenli egzersiz, fiziksel direnci korumak konularının yanında ağız hastalıklarının önlenmesine yönelik diş fırçalama, diş ipi kullanma ve beslenme konularına da yer verilmelidir (36).
Pandemi Döneminde, Bilgi ve Telekomünikasyon Teknolojilerinin Kullanılması

Pandemi döneminde, hekim-hasta ve toplum arasındaki çapraz enfeksiyon riskini minimuma indirmek ve sağlıkta eşitsizlikleri azaltmak için diş hekimliği hizmet sunumunda yeni düzenlemelerin yapılması ve bilgi ve telekomünikasyon teknolojilerinin kullanıldığı yenilikçi yöntemlerin mevcut sisteme entegre 
edilmesi gerekmektedir. Bu dönemde, mevcut sağlık sistemlerini destekleyici bir araç olarak kabul edilen teletıp ve diş hekimliği uygulamaları $(9,10)$ yaşanan kısıtlamalar nedeni ile ağız sağlığı hizmetlerine erişim sorunu yaşayan toplumun ve hastaların bilgilendirilmesinde önemli bir kaynaktır. Modern teknolojiler, hem ağız hastalıklarının tedavi edilmesinde hem de bireylerin kendi sağlıklarını kontrol etme ve sürdürmesine yönelik sağlık eğitimi çalışmalarını içeren birinci basamak sağlık hizmetleri kapsamında yarar sağlayacaktır $(9,10,37)$. Tele-diş hekimliği uygulamaları; bireysel ağız bakımının öğretilmesi, izlenmesi ve ağız sağlığını koruma ve geliştirmeye yönelik kanıta dayalı bilgilerin hastayla paylaşıldığı bir platform olarak kullanılmaktadır (3). Bu uygulamaların yanında, anlık mesajlaşma (WhatsApp, Telegram, Instagram, SMS, Messenger) ve görüntülü arama uygulamaları da (Google Meet, Skype, Facetime, WhatsApp) bir platform olarak koruyucu ağız diş sağlığı mesajlarının topluma iletilmesinde önem kazanmaktadır. $(9,10,38,39)$.

Pandemi sürecinde, tele- diş hekimliği uygulamaları ve akıllı telefonların kullanımı; coğrafik açıdan ulaşım zorluğu yaşayanlar ve kırılgan grupların (engelli ve özel bakım ihtiyacı olanlar, yaşıllar, okullarda yürütülen sağlık hizmetleri kapsamı dışında ağız sağlığı hizmetlerine ulaşamayan okul çocukları, eğitim ve gelir düzeyi düşük gruplar, göçmenler) ağız sağllğı hizmetlerine erişimini sağlama ve hizmete yönlendirme, triyajın sağlanması, toplumsal ihtiyaç değerlendirilmesinin yapılması ve gereksiz sevk veya seyahatten kaçınılması süreçlerinde fayda sağlayacaktır (3-5).

Bunların yanında, halk sağlığı acil durumlarında sağlık bilişim sistemlerinin kullanımı epidemiyologlara, biyoistatistikçilere, halk sağlığı uzmanlarına ve politika yapıcılara, büyük veri toplama, analiz etme, veri ve bilgileri görselleştirme, farklı yöntemleri karşlaştırma ve yeni planlamalar yapma aşamasında yardımcı olacaktır (4).

COVID-19 Pandemisinde Halk Sağlığı Uygulamaları Açısından Sosyal Medyanın Önemi

COVID-19 pandemisi, nüfusun ağız diş sağlığ1 ihtiyaçlarında değişikliklere ve ağız sağlığı bakımı ile ilgili yeni zorluklara neden olmuştur. İnternetten alınan, sosyal medya ve web sitesi aracılığıyla halk arasında paylaşılan tıbbi bilgi miktarı COVID-19 salgını sırasında büyük ölçüde artmıştır. Pandemi döneminde, Google arama motorunda en sık aranılan semptomun “diş ağrısı” olması pandemi dönemindeki kısıtlamaların ağız diş sağlığı tedavi ihtiyacını arttırdığını göstermektedir. Google Trendler' in sürekli izlenmesi, COVID-19 salgını sırasında çok hızlı değişim gösteren toplumsal tedavi ihtiyaçlarının değerlendirilmesinde yardımcı olacaktır (5).

Pandemi döneminde Çin'de ve Tayland'da yapılan çalışmalar; sosyal medyada diş hekimliği hizmetleri, diş tedavisi ihtiyaçları ve evde ağız bakımıyla ilgili bilgiler içeren tweetlerin analiz edilmesinin, devlet kurumları ve ağız sağlığı profesyonellerine kamuoyundaki ağız sağlığına yönelik endişelerin saptanmaSı aşamasında fayda sağlayacağını göstermektedir. Sosyal medya, halk sağlığı politikalarının oluşturulmasında ve halkın bilgilendirilmesinde önemli bir platform olarak karşımıza çıkmaktadır $(40,41)$.

\section{Pandemi Döneminde Toplum Ağız Diş Sağlığı Çalışmalarına Yönelik Etik Yaklaşımlar}

Ülkemizde, diş hekiminin topluma hizmet sunarken uyması gereken etik ilkeler, “Türk Diş Hekimleri Birliği- Diş Hekimliği Meslek Etiği Kuralları” dökümanında belirlenmiştir (42). Pandemi döneminde, halk sağlığ 1 ve tıbbi alanda uygulamaya konulan birçok uygulama beraberinde yeni etik sorunları gündeme getirmiştir. Bu dönemde, diş hekimleri hizmet sunarken bu etik kuralların haricinde Sağlık Bakanlığ 1 ve hükümet tarafından alınan yeni kararlara göre hareket etmek zorunda kalmıştır. Amerikan Diş Hekimleri Birliği, diş hekimlerinin COVID-19 salgını veya herhangi bir acil halk sağlığı durumunda özerklik, zarar vermeme, fayda sağlama, adalet ve doğruluk gibi etik ilkeleri dikkate alarak diş hekimliği pratiğine devam etmeleri için bir rehber yayınlanmıştır (43).

Pandemi dönemiyle birlikte diş hekimliğinin hem halk sağlı̆̆ hem de tedavi kısmında; sosyal mesafe uygulaması, triyaj, hasta bilgilerinin ilgili kurumlarla paylaşılması, acil hasta bakımı, ağız sağlığı hizmetine ulaşımda eşitsizlik, hükümetlerin ve uluslararası toplumun yükümlülükleri, toplum katılımı, kırılgan 
grupların durumu, finansal sorunlar, görev tanımının içinde yer almayan filyasyon, sürüntü alma ve ilaç dağıtma gibi yeni görevlendirmeler nedeni ile kamu ağız diş sağlı̆ğ hizmetlerinde yaşanan gecikmeler, belirli yaş gruplarına getirilen kısıtlamalar nedeni ile ağız diş sağlı̆̆ı hizmetinden yararlanamama, sınırlı kaynakların tahsisi, bulaşıcı hastalık salgınları sırasında araştırma ve hızlı veri paylaşımı, kanıtlanmamış müdahalelerin, ilaç ve aşıların araştırma dışında acil kullanımı gibi konularda yeni etik sorunlar ortaya çıkmaktadır $(6,7,44,45)$.

Salgın durumlarında geçerli olan etik ilkeler; adalet, iyilik, fayda, kişilere saygı, otonomi ve dayanışmadır. Mevcut pandeminin hızla yayılması ve buna bağlı belirsizlik, hangi ilkelere öncelik verilmesi gerektiğine ve hangi eylem tarzının tanımlanan temel ilkelere en iyi şekilde uyacağına karar vermeyi zorlaştırmaktadır. Prosedür etiği, sürece kimin karar vermesi gerektiği ve sürece nasıl dâhil olunacağ hakkında sorular ortaya çıkarmaktadır. Bu kararlar, büyük ölçüde ülkenin siyasi, kültürel, tarihi ve sosyoekonomik bağlamından etkilenir; bu nedenle, ülkeden ülkeye farklılık gösterebilir. Bir ülkede, pandemi döneminde etik ilkelerin belirlenmesine bağlı olarak, pandemiye verilen yanıt değişecektir. Mevcut kaynaklar da, bu yanıta göre epidemiyolojik sürveyans, bireysel tıbbi bakım veya halk sağlığı müdahaleleri arasında dağıtılacaktır (45).

Pan Amerikan Sağlık Örgütü tarafından, halk sağlığı uygulamalarında dikkate alınması gereken etik kurallar aşağıda maddeler halinde özetlenmiştir (46):

-Topluma yönelik sağllğı geliştirmeye yönelik uygulamalardaki etik kurallar eşitlik, sorumluluk, dayanışma ve şeffaflık olmalıdır.

-Toplumun tüm kesimlerini kapsayan sağlığı koruma ve geliştirme çalışmaları kapsamında bilişim teknolojileri ve sosyal medya kullanılarak bilgilendirme yapilırken, bireysel verilerin mahremiyeti ve gizliliğine dikkat edilmeli, gerekli yasal düzenlemelere uyulmalıdır.

-Eşitlik, sorumluluk ve dayanışma etik ilkeleri çerçevesinde kısıtlamalar nedeniyle sağlık hizmetine ulaşamayan çocuk ve yaşlıların, dezavantajlı grupların sağlık hizmetlerinden yararlanabilmesi için diji- tal uygulamalardan triyaj, tedavi önceliklerinin belirlenmesi ve erken tanıda destek alınmalıdır.

- Sağlık otoriteleri, pandemiyle ilgili en son epidemiyolojik bilgiler ışığında mevcut durum ve sonuçlar hakkında halkla doğrudan ve eksiksiz bir şekilde bilgileri paylaşmalıdır. Proaktif olarak prosedürler tasarlamak ve uygulamakla yükümlü olan sağlık otoriteleri, dezavantajlı grupları da dikkate alarak karmaşık sağlık bilgilerini halkın anlayabileceği bir dille ve uygun iletişim teknikleri ile halka yaymalı, pandemi ve sonuçları hakkında sahip olmadıkları bilgiler hakkında dürüst ve şeffaf olmalıdır. Belirsiz konular hakkında beyanlarından kaçınmalı ve belirsizliğin kapsamı konusunda açık ve dürüst olmalıdırlar.

-Sağlık yetkilileri, COVID-19 salgını ve diğer halk sağlığıyla ilgili acil durumlarda toplum sağlığını korumak için sürveyans analizi uygulamak ve güncel güvenilir bilgileri gecikmeden halkın yararı için müdahalelerde kullanmak zorundadır. Uluslararası düzeyde elde ettikleri bilgileri zamanında gerekli önlemlerin alınabilmesi için paylaşmalıdırlar.

-Pandemi sırasında ulusal sağlık otoriteleri tarafından toplanılan kişisel veriler veya örnekler için, ülkeden ülkeye değişmekle birlikte, bilgilendirilmiş onam gerekli olmayabilir. Halk, sağlık verilerinin toplanmasının halk sağlığını iyileştirmek için yürütülen sürveyans çalışmalarının bir parçası olduğunu, bireysel verilerin korunduğu ve gizli bir şekilde yönetileceği ve kullanılacağı konusunda bilgilendirilmelidir. Bu bilgileri anlaşılır bir şekilde sağlamak, halkın güveninin sağlanması için anahtardır. Halka karşı şeffaf olmamak acil durumlarda güvensizliğin artmasına ve uygulamalara karşı direnç göstermesine neden olacaktır.

-Toplumda ayrımcilığa ve damgalamaya neden olacak hassas bilgiler, neden olabilecekleri zararlar minimum düzeyde olacak düzeyde halkla paylaşılmalı ve bu durumlara karşı gerekli önlemler alınmalıdır. Halka verilecek bilgilerde kullanılacak mesajlar kültürel çeşitliliğe duyarlı ve kültürel farklılığa saygilı olmalıdır.

-Yanlış bilgilendirmenin önüne geçmek için haber medyası ve sağlık alanındaki diğer paydaşlarla ortaklık yapılmalıdır. 
-Acil durumlarda yapılan insan denek araştırmaları etik güvencelere sahip olmalıdır. Pandemi döneminde insan denek çalışmaları için çalışma başlamadan etik onayı alınmalıdır. Bilgilendirilmiş onam, acil durumlarda insanlarda uygulanan her çalışmada alınmalıdır. Araştırma ekipleri, araştırmalarının sonuçlarını vakit geçirmeden halk yararını gözeterek halk sağlığı uzmanlarına ve otoritelerine açıklamalıdır. Araştırma ekipleri, gelecek araştırmalara katkı sağlamak için araştırma protokollerini, araçlarını, veri ve örneklerini etik kurallar çevresinde paylaşmalıdır.

Pandemi döneminde, yeterli kapasitesi olan, evde bakım planlarına geçmiş, basitleştirilmiş teknolojiler ve temel sağlik hizmetlerini sürdüren, ilaç tedarikinde özerklik sağlayan, afet durumlarıyla başa çıkma kapasitesi olan, aşılama gibi halk sağlığı hizmetleri sunan güçlü sağlık sistemlerine ihtiyaç vardır (45).

Bu dönemde, ülkemizin de dahil olduğu bazı ülkelerde diş hekimleri birinci basamak sağllk hizmetleri kapsamında, kendi görev tanımlarının içinde yer almayan filyasyon, konsültasyon ve nazofaringeal sürüntü örneği alma aşamalarında görevlendirilmiştir. Hizmet sunumunda, bu görevlendirmelerin etik açdan bir sorun yaratmaması için diş hekimlerinin görev tanımlarıyla ilgili yasal düzenlemelere ihtiyaç olduğu görülmektedir (47).

Sağlık hizmeti kullanan hastaların ve toplumun COVID-19 hastalığına yönelik bilgi düzeyi, algı ve tutumlarını değerlendiren ihtiyaç saptayıcı bilimsel araştırmalara ihtiyaç vardır (47). Bu çalışmalar, ağız diş sağlığ tedavi hizmetlerinin normalleşme döneminde yeniden yapılanmasına ve toplumun ağız diş sağlı̆̆ düzeyinin arttırılmasını hedefleyen strateji ve eylem planlarının hazırlanmasına yol gösterecektir.

'Tek Sağlık' yaklaşımı çerçevesinde, halk sağlığ 1 uygulamalarında multidisipliner çalışmalara ağırlık verilmelidir (48). Ülkemizde, pandemi döneminde topluma yönelik yürütülen ağız diş sağlığını koruma ve geliştirme çalışmaları ile “Toplum Ağız Diş Sağl1ğı Dersi” saha çalışmaları kesintiye uğramıştır. Birinci basamak ağız diş sağlığı hizmetlerinin etkin olarak verilemediği bu dönemde, topluma yönelik ağız diş sağlığı çalışmalarında diş hekimliği öğrencilerinden fayda sağlanabilir. Öğrencilerin, gönüllü tıbbi çalışma, mevcut halk sağlığ 1 ve toplum programlarına katıll$\mathrm{m}$ toplum ağız diş sağlığı sorumluları ve okul yönetimleri tarafından eğitim müfredatının bir parçası olarak planlanmalıdır. Bu planlama, öğrencilerin halk sağlığı acil durumlarında toplumun farklı kesimlerini sosyal ve kültürel açıdan tanımasına, multidisipliner çalışmalar yapmasına, sosyal ve etik değerleri öğrenmesine, toplumsal düzeyde ağız diş sağlığ ihtiyaç tespiti yapabilmesine katkı sağlayacaktır. Yürütülmekte olan bu programlara katılım, geleceğin diş hekimleri olan öğrencilerin klinik becerilerini toplum uygulamalarına entegre edebilme, ekip çalışması yapabilme, iletişim ve liderlik yetkinliklerini de artt1racaktır $(18,47,49)$.

\section{SONUÇ}

Pandemi, halk sağlığında ağız sağlığı eşitsizliklerinin artmasına, topluma yönelik ağız diş sağlığı çalışmalarının ve koruyucu ağız sağlığı hizmetlerinin kısıtlanmasına neden olmaktadır. COVID-19 pandemisinin yönetilmesinde, biyomedikal yaklaşım yalnız başına yeterli değildir. Biyopsikososyal yaklaşım çerçevesinde, toplum sağlığına yönelik eylemler planlanırken sosyal adalet, eşitlik ve insan hakları gibi temel etik kurallar ile sektörler arası işbirliği, çalışma esnekliği ve kapasitesi gibi parametreler dikkate alınmalıdır. Topluma yönelik ihtiyaç değerlendirmelerinde yol gösterici bilimsel çalışmalara, toplum bilgilendirmesinde bilişim teknolojilerinin aktif olarak kullanılmasına, COVID-19 ve diğer halk sağlığ lerinin toplum ağız sağlı̆ğ uygulamalarındaki rolünün ve mevcut eğitim müfredatlarının yeniden yapılandırılmasına ihtiyaç olduğu görülmektedir. Ülkemizde toplumun "COVID-19 ve Ağız Sağlı̆̆ı" konusunda sağlık okuryazarlığını arttırmak için ağız sağlığı otoriteleri tarafından şeffaf ve güvenilir bilgilerin paylaşıldığı kanıta dayalı bilgilendirme platformlarının hazırlanması gerekmektedir. Pandemi döneminde, sürveyans ve halk sağlığı araştırmaları vasıtasıyla toplumun ağız sağlığı ihtiyaçlarının saptanması, ağız diş sağ $\breve{g ̆ g}_{1}$ hizmetlerinin yeniden düzenlenmesinde fayda sağlayacaktır. Toplumda k1- 
sitlamaların uygulandığı ve ağız sağlığı hizmetlerine ulaşımda zorluk yaşayan çocuk ve yaşlıların ağız sağlığının korunması ve geliştirilmesine yönelik çalışmalara öncelik verilmelidir.

Hakem Değerlendirmesi: Dış bağımsız.

Peer Review: Externally peer-reviewed.

Çalışma Konsepti/Tasarım: Ö.D.O., S.İ., G.A.,K.P.,M.M.A.; Veri Toplama- Ö.D.O., S.İ., G.A.,K.P.,M.M.A.; Veri Analizi/Yorumlama- Ö.D.O., S.İ., G.A.,K.P.,M.M.A.; Yazı Taslağ1- Ö.D.O., S.İ., G.A.,K.P.,M.M.A.; İçeriğin Eleştirel İncelemesiÖ.D.O., S.İ., G.A.,K.P.,M.M.A.; Son Onay ve Sorumluluk- Ö.D.O., S.İ., G.A.,K.P.,M.M.A.

Author Contributions: Conception/Design of Study- Ö.D.O., S.İ., G.A.,K.P.,M.M.A.; Data Acquisition- Ö.D.O., S.İ., G.A.,K.P.,M.M.A.; Data Analysis/Interpretation - Ö.D.O., S.İ., G.A.,K.P.,M.M.A.; Drafting Manuscript- Ö.D.O., S.İ., G.A.,K.P.,M.M.A.; Critical Revision of ManuscriptÖ.D.O., S.İ., G.A.,K.P.,M.M.A.; Final Approval and Accountability- Ö.D.O., S.İ., G.A.,K.P.,M.M.A.

Çıkar Çatışması: Yazarlar çıkar çatışması beyan etmemişlerdir

Conflict of Interest: Authors declared no conflict of interest.

Finansal Destek: Yazarlar finansal destek beyan etmemișlerdir.

Financial Disclosure: Authors declared no financial support.

\section{KAYNAKLAR}

1. WHO. WHO Director-General's opening remarks at the media briefing on COVID-19-11 March 2020. (Cited 12.04.2021) Available from URL: https://www.who.int/directorgeneral/ speeches/detail/who-director-generalsopening-remarks-at-the-media-briefingoncovid-19---11-march-2020.

2. Ghani F. Covid-19 Outbreak - Immediate and long-term impacts on the dental profession. Pak J Med Sci 2020;36(COVID19-S4):126-9.

3. Mascitti M, Campisi G. Dental Public Health Landscape: Challenges, Technological Innovation and Opportunities in the 21st Century and COVID-19 Pandemic. Int J Environ Res Public Health 2020;17:3636.

4. Mantas J. The Importance of Health Informatics in Public Health During the COVID-19 Pandemic. Stud Health Technol Inform 2020;272:487-8.

5. Sycinska-Dziarnowska M, ParadowskaStankiewicz I. Dental Challenges and the Needs of the Population during the Covid-19 Pandemic Period. Real-Time Surveillance Using Google Trends. Int J Environ Res Public Health 2020;17(23):8999.

6. Kathree BA, Khan SB, Ahmed R, Maart R, Layloo N, Asia-Michaels W. COVID-19 and its impact in the dental setting: A scoping review. PLoS ONE 2020;15(12): e0244352

7. Elster N, Parsi, K. Oral Health Matters: The Ethics of Providing Oral Health During COVID-19. HEC Forum 2021; 33(1-2):157-64.

8. Watt RG. COVID-19 is an opportunity for reform in dentistry. Lancet 2020; 15;396(10249):462.

9. Singh S. Public Oral Health Care During COVID-19: Time for Reflection and Action. Front Med (Lausanne) 2021;8:610450.

10. Daly J, Black EAM. The impact of COVID-19 on population oral health. Community Dent Health 2020;37(4):236-8.

11. Shamsoddin E, DeTora LM, Tovani-Palone MR, Bierer BE. Dental Care in Times of the COVID-19 Pandemic: A Review. Med Sci 2021;9(1):13.

12. WHO. Considerations for the provision of essential oral health services in the context of COVID-19. (Cited 21.04.2021) Available from URL: https://www.who.int/publications/i/item/ who-2019-nCoV-oral-health-2020.1.

13. Benzian H, Beltrán-Aguilar E, Mathur MR, Niederman R. Pandemic Considerations on Essential Oral Health Care. J Dent Res 2021;100(3):221-5.

14. Abrams EM, Szefler SJ. COVID-19 and the impact of social determinants of health. Lancet Respir Med 2020; 8(7): 659-61.

15. Schwendicke F, Krois J, Gomez J. Impact of SARS-CoV2 (Covid-19) on dental practices: Economic analysis. J Dent 2020;99:103387.

16. Brian Z, Weintraub JA. Oral Health and 
COVID-19: Increasing the Need for Prevention and Access. Prev Chronic Dis 2020;17:E82. Erratum in: Prev Chronic Dis 2020;17:E93.

17. Kalash DA. How COVID-19 deepens child oral health inequities. J Am Dent Assoc 2020;151(9):643-5.

18. Westgarth, D. COVID-19 and Community Dental Services: The challenges ahead. BDJ In Pract 2020;33: 14-9.

19. Şahin B, İlgün G. Assessment of the efficiency of dental services in Turkey. Health Policy Technol 2018: 7(2): 173-81.

20. T.C. Sağlık Bakanlığı Halk Sağlığı Genel Müdürlüğü. 2019 Yılı Birim Faaliyet Raporu. (Cited 15.03.2021) Available from URL: https:// hsgm.saglik.gov.tr/depo/birimler/izlemedegerlendirme-db/faaliyet-raporu/2019_DDB_ BRM_FAALYET_RAPORU.pdf.

21. Üstün N, Akgöl BB, Bayram M. Influence of COVID-19 pandemic on paediatric dental attendance. Clin Oral Investig 2021;30:1-7.

22. Luo W, Lee GHM, Nalabothu P, Kumar H. Paediatric dental care during and postCOVID-19 era: Changes and challenges ahead. Pediatr Dent J 2021;31(1):33-42.

23. León S, Giacaman RA. COVID-19 and Inequities in Oral Health Care for Older People: An Opportunity for Emerging Paradigms. JDR Clin Trans Res 2020;5(4):290-2.

24. Alharbi A, Alharbi S, Alqaidi S. Guidelines for dental care provision during the COVID-19 pandemic. Saudi Dent J 2020; 32(4): 181-6.

25. Scrapping PHE, a threat to oral health?. Br Dent J 2020;229(5):272.

26. Bains R, Bains VK. Oral health care, COVID-19 and challenges. J Global Oral Health 2020;3(2):130-6.

27. Silva Dayane Helen Ferreira, Camargos Júlia Hinkelmann de, Rodrigues Jefferson Guimarães, Nogueira Leilismara Sousa, Azevedo Dênia Alves de, Carvalho Maria das Graças et al . Impact of oral hygiene in patients undergoing mechanical ventilation in the COVID-19 pandemic. Rev. Assoc. Med. Bras. [Internet]. 2020 [cited 2021
May 06] ;66( Suppl 2 ): 96-101.

28. Sampson V. Oral hygiene risk factor. Br Dent J 2020;228(8):569.

29. Moosavi MS, Aminishakib P, Ansari M. Antiviral mouthwashes: possible benefit for COVID-19 with evidence-based approach. J Oral Microbiol 2020;12(1):1794363.

30. Cavalcante-Leão BL, de Araujo CM, Basso IB, Schroder AG, Guariza-Filho O, Ravazzi GC, Gonçalves FM, Zeigelboim BS, Santos RS, Stechman-Neto J. Is there scientific evidence of the mouthwashes effectiveness in reducing viral load in Covid-19? A systematic review. J Clin Exp Dent 2021;13(2):179-89.

31. Lloyd-Jones G, Molayem S, Pontes CC, Chapple I. The COVID-19 Pathway: A Proposed OralVascular-Pulmonary Route of SARS-CoV-2 Infection and the Importance of Oral Healthcare Measures. J Oral Med and Dent Res 2021; 2(1):125.

32. Dental Health Foundation Ireland. Tooth Brushing Coronavirus and COVID 19. Available from: www.dentalhealth.ie/assets/files/pdf/ toothbrushes_-_covid_19_april_2020.pdf. (Alintılama tarihi 10.02.2021).

33. Canadian Dental Hygienists Association. Caring for Your Oral Health During the COVID-19 Pandemic. The Canadian Dental Hygenist Assosiation. (Cited 10.02.2021) Available from URL:https://www.dentalhygienecanada.ca/ dhcanada/DHCanada/Preventive_Oral_Care/ Oral_Health_During_COVID19.aspx.

34. FDI. Fact sheet: Protect your oral health during the COVID-19 pandemic. (Cited 10.03.2021) Available from URL:https:// www.worldoralhealthday.org/sites/default/ files/2021-01/WOHD21-factsheet-covid19-EN. pdf.

35. FDI. As COVID-19 shifts learning online, FDI supports parents and teachers with digital resources on oral health education. (Cited 10.03.2021) Available from URL:https:// https:// www.fdiworlddental.org/covid-19-shiftslearning-online-fdi-supports-parents-andteachers-digital-resources-oral-health. 
36. Wang Y, Zhou CC, Shu R, Zou J. Oral Health Management of Children during the Epidemic Period of Coronavirus Disease 2019. Sichuan Da Xue Xue Bao Yi Xue Ban 2020;51(2):151-4.

37. da Costa CB, Peralta FDS, Ferreira de Mello ALS. How Has Teledentistry Been Applied in Public Dental Health Services? An Integrative Review. Telemed J E Health 2020;26(7):945-54.

38. Maret D, Peters OA, Vaysse F, Vigarios E. Integration of telemedicine into the public health response to COVID-19 must include dentists. Int Endod J 2020;53(6):880-1.

39. Telles-Araujo GT, Caminha RDG, Kallás MS, Santos PSDS. Teledentistry support in COVID-19 oral care. Clinics (Sao Paulo) 2020;75:e2030.

40. Tao Z, Chu G, McGrath C, Hua F, Leung YY, Yang W, Su Y. Nature and Diffusion of COVID-19related Oral Health Information on Chinese Social Media: Analysis of Tweets on Weibo. J Med Internet Res 2020;22(6):e19981.

41. Boon-Itt S, Skunkan Y. Public Perception of the COVID-19 Pandemic on Twitter: Sentiment Analysis and Topic Modeling Study. JMIR Public Health Surveill 2020;6(4):e21978.

42. TDB. Türk Dişhekimleri Birliği Diş Hekimliği Meslek Etiği Kuralları. Türk Diş hekimleri Birliği Yayınları- Mevzuat Dizisi, Ekim 2013, Ankara.
43. ADA. Guidance on Continuing to Practice Ethically during COVID-19. (Cited 10.02.2021) Available from URL:https://success.ada.org/ / media/CPS/Files/COVID/ADA_COVID_ How_Do_I_Ethically_See_Patients_During Pandemic.pdf.

44. Ethics Subcommittee of the Council on Ethics, Bylaws and Judicial Affairs. Ethical practice during the COVID-19 pandemic. J Am Dent Assoc 2020;151(5):377-8.

45. Saxena A, Bouvier PA, Shamsi-Gooshki E, Köhler J, Schwartz LJ. WHO guidance on ethics in outbreaks and the COVID-19 pandemic: a critical appraisal. J Med Ethics 2021:106959.

46. Pan American Health Organization.Ethics guidance on issues raised by the novel coronavirus disease (COVID-19) pandemic. (Cited 20.02.2021) Available from URL: https:// iris.paho.org/handle/10665.2/52091.

47. Seneviratne CJ, Lau MWJ, Goh BT. The Role of Dentists in COVID-19 Is Beyond Dentistry: Voluntary Medical Engagements and Future Preparedness. Front Med (Lausanne) 2020;7:566.

48. Jorwal P, Bharadwaj S, Jorwal P. One health approach and COVID-19: A perspective. J Family Med Prim Care 2020;9(12):5888-91.

49. Liu C, Onudiwe F. The 'new normal' in oral health promotion. Br Dent J 2020;229(10):6412. 
